\title{
ANALISIS PENGARUH BERBAGAI MACAM MERK OLI TERHADAP TEMPERATUR MESIN YAMAHA VIXION 150CC
}

\author{
Aris Budi Perlindungan"1), Aqli Mursadin²) \\ 1,2 Program Studi Teknik Mesin \\ Fakultas Teknik Universitas Lambung Mangkurat \\ JL. Akhmad Yani Km.36 Banjarbaru Kalimantan Selatan, 70714 \\ Telp. 087817152622 \\ E-mail : ariezperlindungann@gmail.com
}

\begin{abstract}
Abstrak, Penelitian ini bertujuan untuk mengetahui pengaruh berbagai macam merk oli terhadap temperatur, emisi gas buang, dan performa pada mesin yamaha vixion $150 \mathrm{cc}$. penelitian ini dilakukan dengan mengambil data temperatur, emisi gas buang, dan performa mesin yamaha vixion $150 \mathrm{cc}$. Penelitian ini menggunakan tiga jenis oli yang berbeda yaitu oli yamalube super sport, shell advance ax7,dan pertamina enduro. Pengujian temperatur dilakukan pada putaran mesin 1.500 rpm,4000 rpm dan $10.500 \mathrm{rpm}$ dengan menggunakan gear netral, 1, 2, 3, 4, dan 5. Pengambilan data temperatur dilakukan setiap10 menit sekali sampai 30 menit untuk sekali pengujian tiap jenis oli. Pengujian emisi gas buang dilakukan pada putaran mesin 1.500, 4000,dan 10.500 rpm untuk sekali pengujian tiap jenis oli. Pengujian performa dilakukan menggunakan dyno test untuk sekali pengujian tiap jenis oli. Setelah data di dapat dan di olah lalu dibandingkan hasil data temperatur, emisi gas buang, dan performa dari tiap jenis oli.

Hasil pengujian temperatur didapat oli yang paling baik yaitu menggunakan oli yamalube. pengujian Emisi gas buang emisi gas buangn yang paling rendah yaitu oli shell advance Ax7. Oli shell Ax7 menghasilkan emisi gas buang paling rendah di antara oli lainya sedangkan oli enduro melebi batas standar emisi gas buang CO di rpm 10.500 mencapai 5,42\% sedangkan standarnyan yaitu 4,50\%. Pengujian performa yang paling baik yaitu menggunakan oli enduro karena oli enduro dapat menghasilkan daya paling besar yaitu $13.55 \mathrm{Hp}$.
\end{abstract}

Kata kunci : Dyno test (pengujian performa)

Abstract, This study aims to determine the effect of various brands of oil against temperature, exhaust emissions, and performance on the engine yamaha vixion $150 \mathrm{cc}$. This study was conducted by taking temperature data, exhaust emissions, and engine performance yamaha vixion 150cc. This research uses three different types of oil, namely super yamalube sport oil, ax7 advanced shell, and pertamina enduro. Temperature testing is performed at engine speed of 1,500 rpm, $4000 \mathrm{rpm}$ and 10,500 rpm using neutral gear, 1, 2, 3, 4, and 5. Temperature data collection is done every 10 minutes once to 30 minutes for a single test of each type of oil. The exhaust emission test is carried out at engine speeds of 1,500, 4000, and $10,500 \mathrm{rpm}$ for one test of each type of oil. Performance tests are performed using a dyno test for one test of each type of oil. Once the data in can and in the past compared the results of temperature data, exhaust emissions, and the performance of each type of oil.

The best oil temperature test result is using yamalube oil. testing The lowest exhaust gas emission gas emissions are advanced $A x 7$ shell oil. Ax7 shell oil produces the lowest exhaust emissions among other oils while enduro oil exceeds the standard exhaust 
emission limits of $\mathrm{CO}$ at $10,500 \mathrm{rpm}$ to $5.42 \%$ while the standard is $4.50 \%$. Testing the best performance is using enduro oil because enduro oil can produce the greatest power $13.55 \mathrm{Hp}$.

\section{Keywords : Keywords : Diyno test (performance test)}

\section{PENDAHULUAN}

Era globalisasi saat ini harus diakui hampir semua kalangan masyarakat baik kalangan atas, menengah ataupun bawah di indonesia sudah mengenal bahkan sudah menggunakan kendaraan bermotor roda dua. Kendaraa-kendaraan ini juga sudah di anggap sebagai suatu kebutuhan yang harus dipenuhi, mengingat banyak jenis kendaraan terutama jenis kendaraan sepeda motor roda dua yang menawarkan produknya dengan harga murah sehingga dapat di jangkau oleh konsumen kalangan kelas bawah. Akibat dari persaingan harga tersebut sehingga menimbulkan dampak yaitu banyak di jalan kita lihat jenis ataupun berbagai merk kendaraan tersebut yang berujung pada gangguan lalulintas dan kemacetan lalulintas hal ini menyebabkan perusahaan berusaha lebih keras lagi agar produknya dapat di terima oleh konsumen. Sehingga perusahaan harus mampu menghasilkan produk dengan kualitas yang dapat bersaing.

Pelumas adalah zat kimia yang umumnya cairan, yang diberikan antara dua benda bergerak untuk mengurangi gesekan. Pelumas merupakan aktifitas yang penting di dalam pengoprasian mesin. Pemberian minyak pelumas bertujuan untuk mengurangi gesekan dan keausan antar komponen mesin yang saling bergesekan. Gesekan dan keausan yang terjadi dapat menyrbabkan temperatur di sekitar mesin meningkat dan akan terus meningkat. Apabila gesekan ini tidak diatasi, akan mempengaruhi kinerja suatu mesin yang dapat menyebabkan berkurangnya umur mesinn dan kegagalan mesin. Hal ini membawa suatu kerugian kepada suatu industri karena berpengaruh produktifitas dan pengeluaran biaya yang besar untuk perbaikan mesin. Cara kerja pelumas adalah dengan membentuk oil film pada permukaan yang saling bergesekan. Oli film yang terbentuk sangat berpengaruh pada temperatur yang dihasilkan.

Pelumas yang baik adalah yang tidak mudah mengalami perubahan viskositas jika mengalami peningkatan temperatur. Keberhasilan sistem pelumasan pada suatu mesin sngat di perlukan. Keberhasilan pelumasan di tentukan oleh tiga aspek, yaitu jenis pelumas,jumlah pelumas, dan metode pelumasan. Dengan pemilihan dan penggunaan pelumasan yang tepat diharapkan dapat mengatasi gesekan dan keausan yang berlebih sehingga dapat memperpanjang umur mesin dan pengeluaran biaya jadi berkurang. Oleh karena itu, dilakukan penujian pada pelumas dengan viskositas yang berbeda terhadap pembentukan oil film sehingga gesekan lansung antara logam dapat terhindarkan. Dimana pengujian ini dilakukan pada mesin dengan mengunakan pelumas. Fungsi oli diantaranya memperlancar kerja mesin agar gesekan yang ada dapat diredam, meberi lapisan pelindung pada onderdil-onderdil yang saling bergesekan sehingga keausan dan kerusakan yang memungkinkan terjadi dapat di cegah seminimal mungkin, dan sebagai pendingin.

Kebanyakan oli sintetis merupakan produk impor dan proses pembuatanya cukup rumit, sehingga harga oli sintetis jauh lebih mahal daripada oli mineral. Oli sintetis pada umumnya mempunyai titik tuang yang rendah dibandingkan dengan oli jenis mineral dan kebanyakan di pergunakan untuk kendaraan yang sering di pacu dengan kecepatan yang lebih tinggi seperti balap, cocok digunakan kondisi ekstrim misalnya musum dingin, daerah tropis yang memiliki temperatur udara 
bervariasi sepanjang tahun antara $22^{\circ} \mathrm{C}-28^{\circ} \mathrm{C}$. Hal ini menunjukan suhunya cukup stabil, tidak terlalu panas dan tidak terlalu dingin.

Latar belakang masalah diatas maka diadakan penelitian yang berhubungan dengan perpindahan panas, dengan mengambil judul " ANALISIS PENGARUH BERBAGAI MACAM MERK OLI TERHADAP MESIN YAMAHA VIXION 150CC".

\section{METODE PENELITIAN}

Metode dalam penelitian ini yang digunakan adalah metode eksperimen

\section{Tempat Penelitian}

Penelitian eksperimen ini dilakukan pada tiga tempat yaitu: uji temperatur dilakukan di laboratorium Teknik Mesin universitas Lambung Mangkurat, uji emisi gas buang di lakukan di Dinas lingkungan hidup Banjarmasin dan uji performa dilakukan di bengkel PNP Banjarmasin.

Adapun teknik pengumpulan data di lakukan dengan cara sebagai berikut:

- Uji temperatur

- Mempersiapkan alat dan bahan

- Nyalakan mesin dan stopwatch

- Ambil temperatur pada kepala silinder setiap 10 menit sekali hingga 30 menit

- Catat temperatur yang dihasilkan

- mengulang langkah diatas menggunakan oli yang berbeda

- uji emisigas buang

- mempersiapkan alat dan bahan

- nyalakan mesin

- stabilkan mesin pada putaran $1.500 \mathrm{rpm}, 4.000 \mathrm{rpm}$, dan $10.500 \mathrm{rpm}$

- ambil data emisi gas buang menggunakan Gas analizer pada putaran mesin 1.500rpm, 4.000rpm, dan 10.500rpm

- catat emisi gas buang yang dihasilkan

- mengulang langkah diatas menggunakan oli yang berbeda.

- Uji performa

- Siapkan alat dan bahan

- Nyalakan mesin

- ambil data menggunakan dyno test

- lakukan langkah diatas menggunakan oli yang berbeda 


\section{HASIL DAN PEMBAHASAN}

Untuk pengujian terhadap suhu mesin dilakukan pada putaran mesin 1.500, 4.000, dan 10.500 rpm dengan menggunakan gear 0 (netral), 1,2,3,4, dan 5 denga suhu malam. Pengambilan data dilakukan setiap 10 menit sekali sampai 30 menit untuk sekali pengujian. Dari penelitian yang telah dilakukan, diperoleh data yang ditunjukan dalam Tabel 1 - Tabel 3.

Tabel 1 Hasil Temperatur Mesin Menggunakan Oli Yamalube

\begin{tabular}{|c|c|c|c|c|c|c|}
\hline \multirow{2}{*}{ Waktu } & \multicolumn{6}{|c|}{ Gear } \\
\hline & $\mathrm{N}$ & 1 & 2 & 3 & 4 & 5 \\
\hline $\begin{array}{c}10 \\
\text { menit }\end{array}$ & $\begin{array}{l}0 \\
\stackrel{0}{\infty} \\
\stackrel{\infty}{\infty}\end{array}$ & $\begin{array}{l}0 \\
\infty \\
\tilde{\infty} \\
\tilde{\infty}^{2}\end{array}$ & $\frac{0}{\tilde{0}}$ & $\begin{array}{l}0 \\
\text { O } \\
\text { の } \\
\infty \\
\infty\end{array}$ & 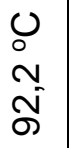 & $\begin{array}{l}0 \\
\nabla^{\prime} \\
\dot{\sigma}\end{array}$ \\
\hline $\begin{array}{c}20 \\
\text { menit }\end{array}$ & $\begin{array}{l}0 \\
\tilde{D}^{-}\end{array}$ & $\begin{array}{l}0 \\
\overline{0} \\
\dot{\infty}\end{array}$ & $\begin{array}{l}0 \\
\text { ஸ } \\
\infty \\
\infty\end{array}$ & $\begin{array}{l}0 \\
0 \\
0 \\
8 \\
8\end{array}$ & $\begin{array}{l}0 \\
m \\
m \\
\text { m. }\end{array}$ & $\begin{array}{l}0 \\
\hat{\Lambda} \\
\text { ஸे }\end{array}$ \\
\hline $\begin{array}{c}30 \\
\text { menit }\end{array}$ & $\begin{array}{l}0 \\
\infty \\
\infty \\
\sigma\end{array}$ & $\begin{array}{l}0 \\
\text { مे } \\
\text { ले }\end{array}$ & $\begin{array}{l}0 \\
0 \\
0 \\
\text { ది }\end{array}$ & $\begin{array}{l}\text { N } \\
\overline{0} \\
0\end{array}$ & $\begin{array}{l}\infty \\
\operatorname{Lin}^{-1}\end{array}$ & $\begin{array}{l}\stackrel{n}{ } \\
\stackrel{\circ}{\circ}\end{array}$ \\
\hline
\end{tabular}

Tabel 2 Hasil Temperatur Mesin Menggunakan Oli Shell Advance Ax7

\begin{tabular}{|c|c|c|c|c|c|c|}
\hline \multirow[t]{2}{*}{ Waktu } & \multicolumn{6}{|c|}{ Gear } \\
\hline & $\mathrm{N}$ & 1 & 2 & 3 & 4 & 5 \\
\hline $\begin{array}{c}10 \\
\text { Menit }\end{array}$ & $\begin{array}{l}0 \\
0 \\
0 \\
\infty \\
\infty\end{array}$ & $\begin{array}{l}0 \\
0 \\
\nabla_{-} \\
\infty\end{array}$ & $\begin{array}{l}0 \\
0 \\
10 \\
\sigma\end{array}$ & $\begin{array}{l}0 \\
0 \\
0 \\
\text { ס' }\end{array}$ & $\begin{array}{l}\text { O } \\
\text { +े } \\
\text { ठे }\end{array}$ & $\begin{array}{l}0 \\
\overline{0} \\
\overline{10}\end{array}$ \\
\hline $\begin{array}{c}20 \\
\text { Menit }\end{array}$ & $\begin{array}{l}0 \\
0 \\
\text { m } \\
\text { g' }\end{array}$ & $\begin{array}{l}0 \\
0 \\
N \\
\text { N }\end{array}$ & $\begin{array}{l}0 \\
0 \\
\text { m } \\
\infty \\
\infty\end{array}$ & $\begin{array}{l}\text { O } \\
\text { No } \\
\infty^{-}\end{array}$ & $\begin{array}{l}\text { O } \\
\text { m } \\
\text { ले }\end{array}$ & $\begin{array}{l}0 \\
0 \\
\infty \\
0 \\
0\end{array}$ \\
\hline $\begin{array}{c}30 \\
\text { Menit }\end{array}$ & $\begin{array}{l}0 \\
0 \\
0 \\
0\end{array}$ & $\begin{array}{l}0 \\
0 \\
\infty \\
\\
0\end{array}$ & $\begin{array}{l}0 \\
0 \\
0 \\
8 \\
0\end{array}$ & $\begin{array}{l}0 \\
0 \\
\tilde{N} \\
\stackrel{N}{\square}\end{array}$ & $\begin{array}{l}0 \\
0 \\
0 \\
10 \\
\square \\
\end{array}$ & $\begin{array}{l}0 \\
0 \\
\hat{0} \\
\underline{T}\end{array}$ \\
\hline
\end{tabular}


Tabel 3 Hasil Temperatur Mesin Menggunakan Oli Pertamina Enduro

\begin{tabular}{|c|c|c|c|c|c|c|}
\hline \multirow[t]{2}{*}{ Waktu } & \multicolumn{6}{|c|}{ Gear } \\
\hline & $\mathrm{N}$ & 1 & 2 & 3 & 4 & 5 \\
\hline $\begin{array}{c}10 \\
\text { Menit }\end{array}$ & $\begin{array}{l}0 \\
0 \\
0 \\
\infty\end{array}$ & $\begin{array}{l}0 \\
0 \\
1 \\
\sigma \\
\sigma\end{array}$ & $\begin{array}{l}\text { U } \\
\infty \\
\text { ๙ } \\
\sigma\end{array}$ & $\begin{array}{l}0 \\
0 \\
\text { o } \\
\text { ठే }\end{array}$ & $\begin{array}{l}0 \\
0 \\
N \\
\tilde{n} \\
\text { बे }\end{array}$ & $\begin{array}{l}0 \\
\text { O } \\
\text { के } \\
\text { o }\end{array}$ \\
\hline $\begin{array}{c}20 \\
\text { Menit }\end{array}$ & $\begin{array}{l}0 \\
0 \\
1 \\
\text { ஸ் } \\
0\end{array}$ & $\begin{array}{l}0 \\
0 \\
0 \\
0\end{array}$ & $\begin{array}{l}\text { U } \\
\text { m } \\
\infty \\
\infty\end{array}$ & $\begin{array}{l}0 \\
\bar{\sigma} \\
\bar{\sigma}\end{array}$ & $\begin{array}{l}\text { ல } \\
\text { o } \\
\text { ఠ' }\end{array}$ & 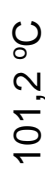 \\
\hline $\begin{array}{c}30 \\
\text { Menit }\end{array}$ & $\begin{array}{l}0 \\
0 \\
\sim \\
\tilde{m} \\
\Gamma\end{array}$ & $\begin{array}{l}0 \\
0 \\
\infty \\
\\
\mp\end{array}$ & \begin{tabular}{l}
0 \\
0 \\
$\infty$ \\
\multirow{+}{+}{} \\
$\mp$
\end{tabular} & $\begin{array}{l}0 \\
0 \\
\sim \\
\tilde{N}^{\circ} \\
\Gamma\end{array}$ & $\begin{array}{l}0 \\
0 \\
m \\
0 \\
\sigma\end{array}$ & $\begin{array}{l}0 \\
0 \\
\infty \\
N \\
\mp\end{array}$ \\
\hline
\end{tabular}

\section{Grafik Hubungan Waktu Dengan Temperatur}

Dari hasil penelitian data yang telah diperoleh maka dapat di hasilkan grafik temperatur mesin yang ditunjukan dalam Gambar 2 - Gambar 7.

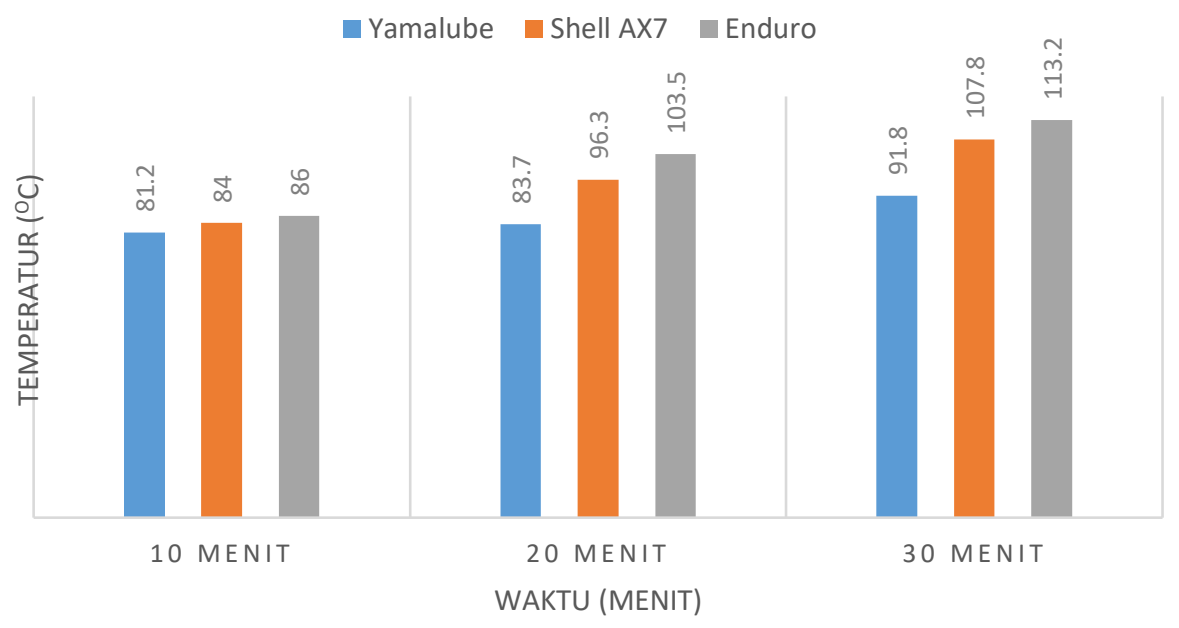

Gambar 2 Grafik hubungan waktu dengan temperatur pada gear netral 


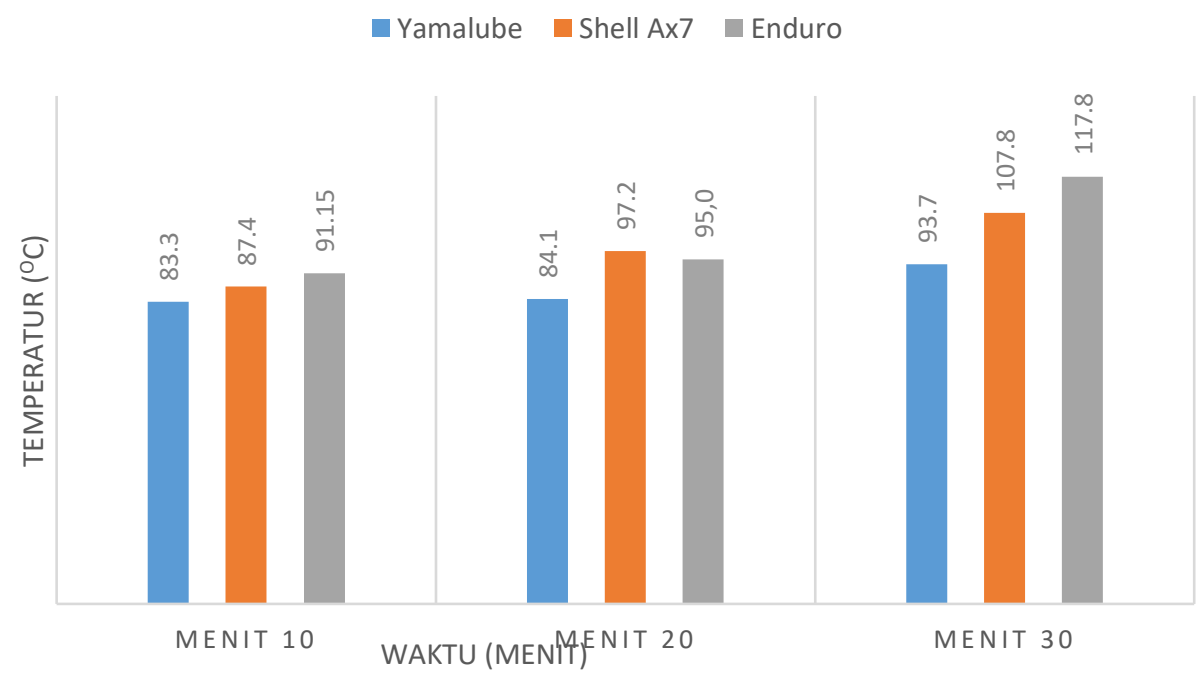

Gambar 3 Grafik hubungan waktu dengan temperatur pada gear 1

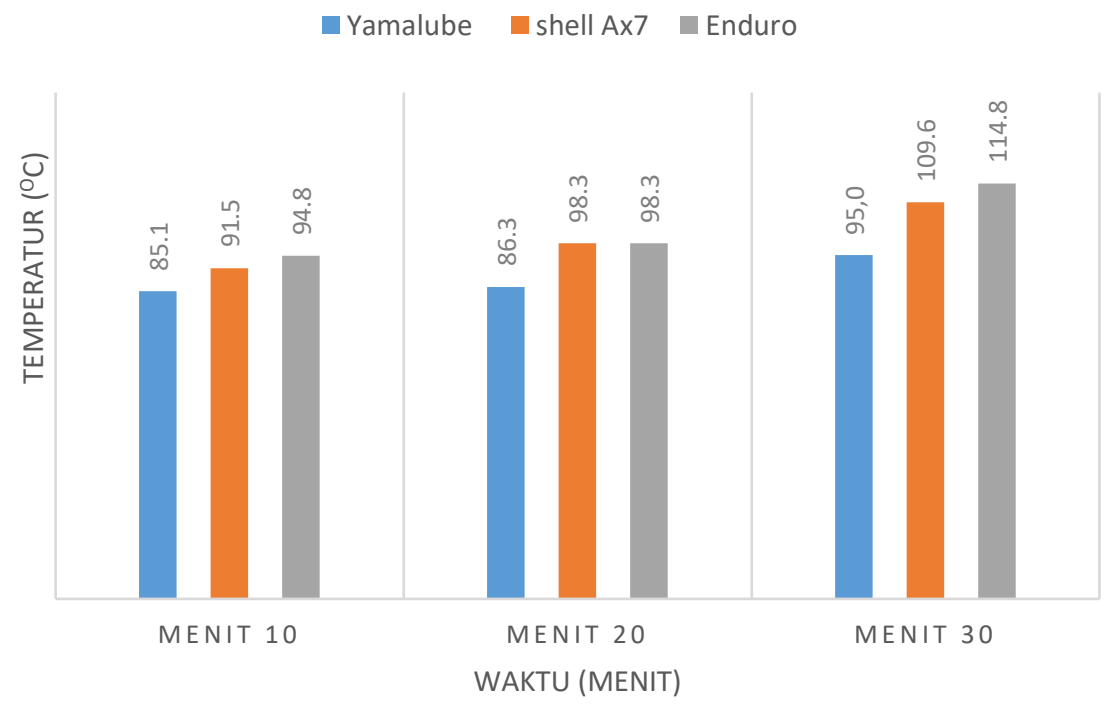

Gambar 4 Grafik hubungan waktu dengan temperatur pada gear 2

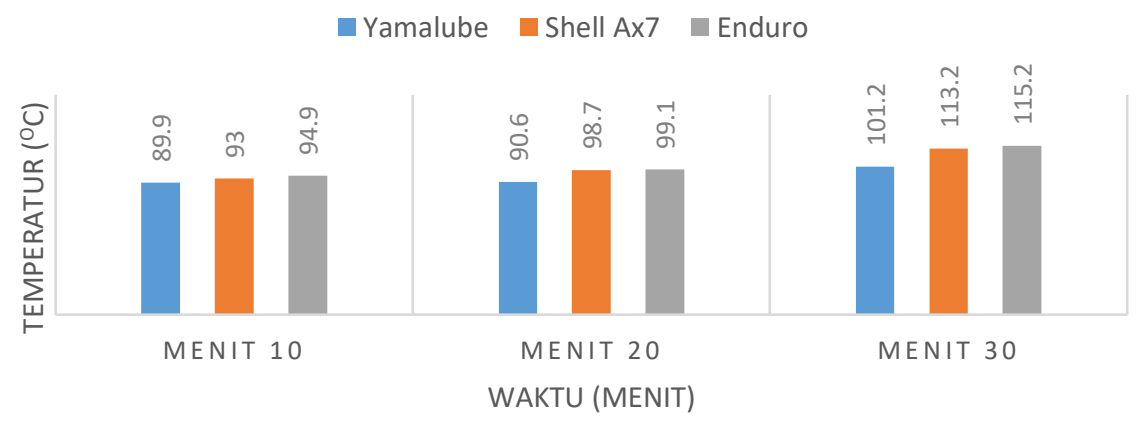

Gambar 5 Grafik hubungan waktu dengan temperatur pada gear 3 


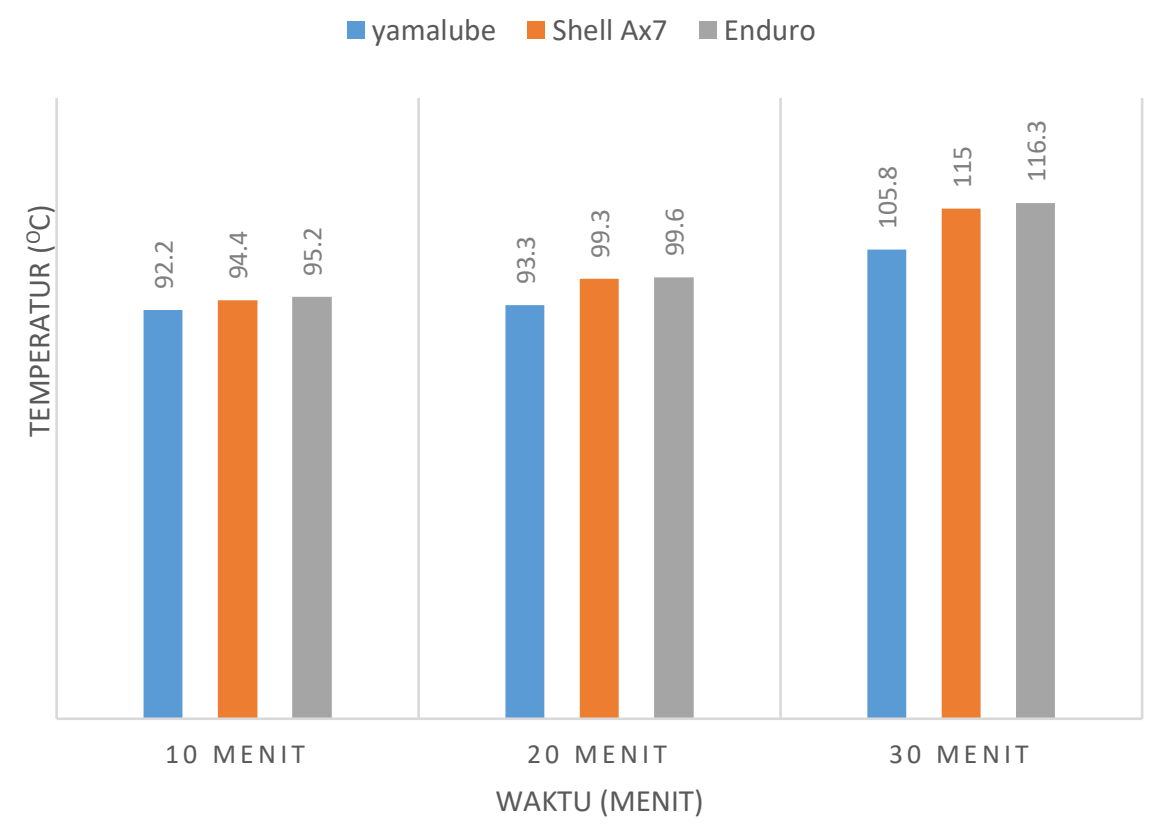

Gambar 6 Grafik hubungan waktu dengan temperatur pada gear 4

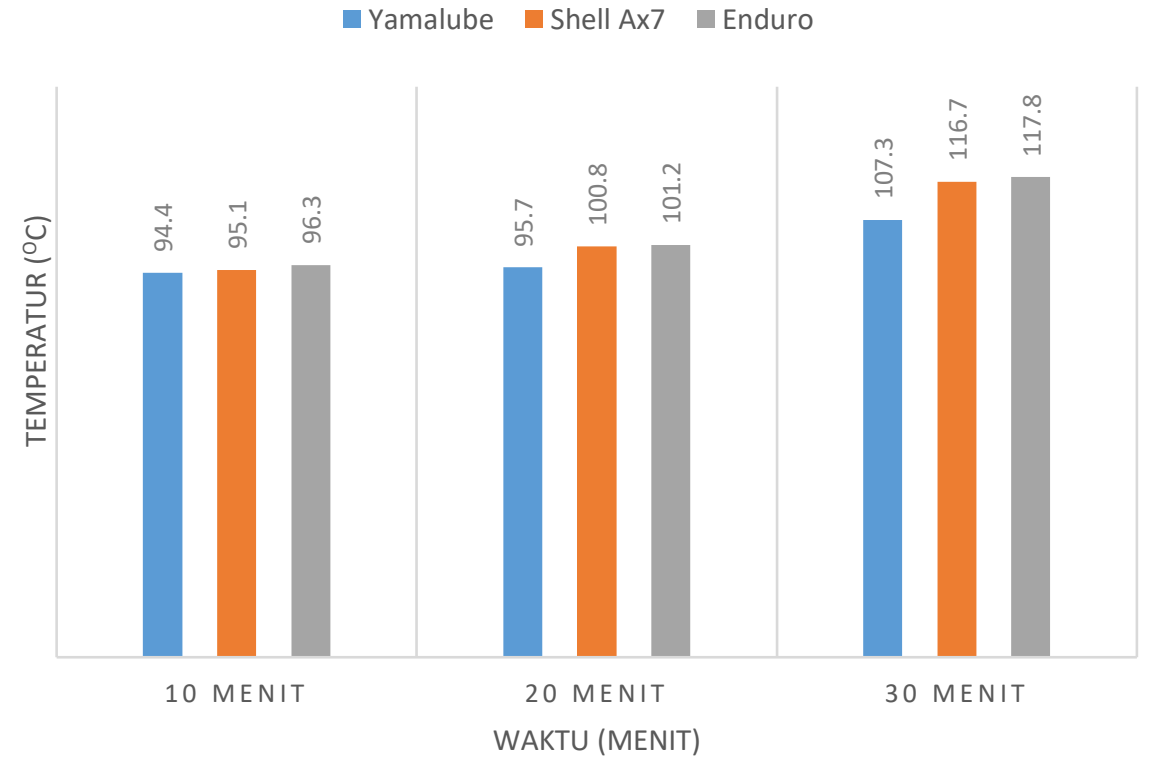

Gambar 7 Grafik hubungan waktu dengan temperatur pada gear 5 


\section{Hasil Pengujian Emisi Gas Buang}

Hasil pengujian emisi gas buang dapat diligat dalam Tabel 4 - Tabel 6.

Tabel 4 Hasil Pengujian Emisi Gas Buang Menggunakan Oli Yamalube

Analisa Hubungan Emisi Gas buang Dengan Rpm dapat kita lihat pada grafik dibawah:

\begin{tabular}{|c|c|c|c|c|}
\hline 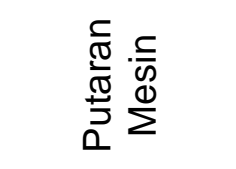 & $\underset{\substack{O \\
\mathbb{U} \\
\mathbb{O}}}{\stackrel{0}{0}}$ & 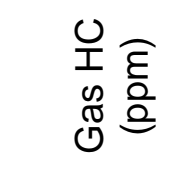 & $\underset{\substack{0 \\
\mathbb{U}}}{\stackrel{0}{0}}$ & $\underset{\widetilde{N}}{\mathbb{N}} \underset{0}{0}$ \\
\hline $\begin{array}{l}1.500 \\
\text { (rpm) }\end{array}$ & 3,56 & 491 & 3,48 & 12,17 \\
\hline $\begin{array}{l}4.000 \\
\text { (rpm) }\end{array}$ & 0,25 & 78 & 6,25 & 11,42 \\
\hline $10.500(\mathrm{rpm})$ & 2,26 & 432 & 7,68 & 7,83 \\
\hline
\end{tabular}

Tabel 5 Hasil Pengujian Emisi Gas Buang Menggunakan Oli Shell Ax7

\begin{tabular}{|c|c|c|c|c|}
\hline 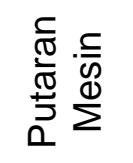 & 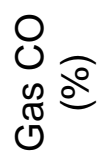 & 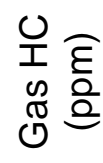 & 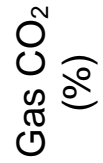 & 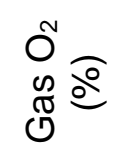 \\
\hline $\begin{array}{l}1.500 \\
\text { (rpm) }\end{array}$ & 3,01 & 292 & 4,51 & 11,18 \\
\hline $\begin{array}{l}4.000 \\
\text { (rDm) }\end{array}$ & 0,17 & 73 & 4,47 & 13,50 \\
\hline $\begin{array}{c}10.500 \\
\text { (rpm) }\end{array}$ & 2,82 & 389 & 7,94 & 6,36 \\
\hline
\end{tabular}

Tabel 6 Hasil Pengujian Emisi Gas Buang Menggunakan Oli Pertamina Enduro

\begin{tabular}{|c|c|c|c|c|}
\hline 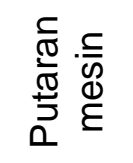 & $\underset{\substack{0 \\
\mathbb{0} \\
0}}{\stackrel{0}{0}}$ & $\begin{array}{l}\stackrel{0}{1} \widehat{\underline{\varepsilon}} \\
\mathbb{O} \\
\stackrel{\mathbb{0}}{0}\end{array}$ & 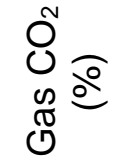 & 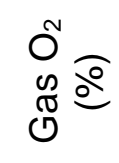 \\
\hline $\begin{array}{l}1.500 \\
\text { (rpm) }\end{array}$ & 1,56 & 210 & 3,22 & 13,59 \\
\hline $\begin{array}{l}4.000 \\
(\mathrm{rpm})\end{array}$ & 0,28 & 71 & 6,01 & 11,28 \\
\hline $\begin{array}{c}10.500 \\
(\mathrm{rpm})\end{array}$ & 5,42 & 235 & 10,22 & 1,16 \\
\hline
\end{tabular}


- Yamalube shellax7 Enduro

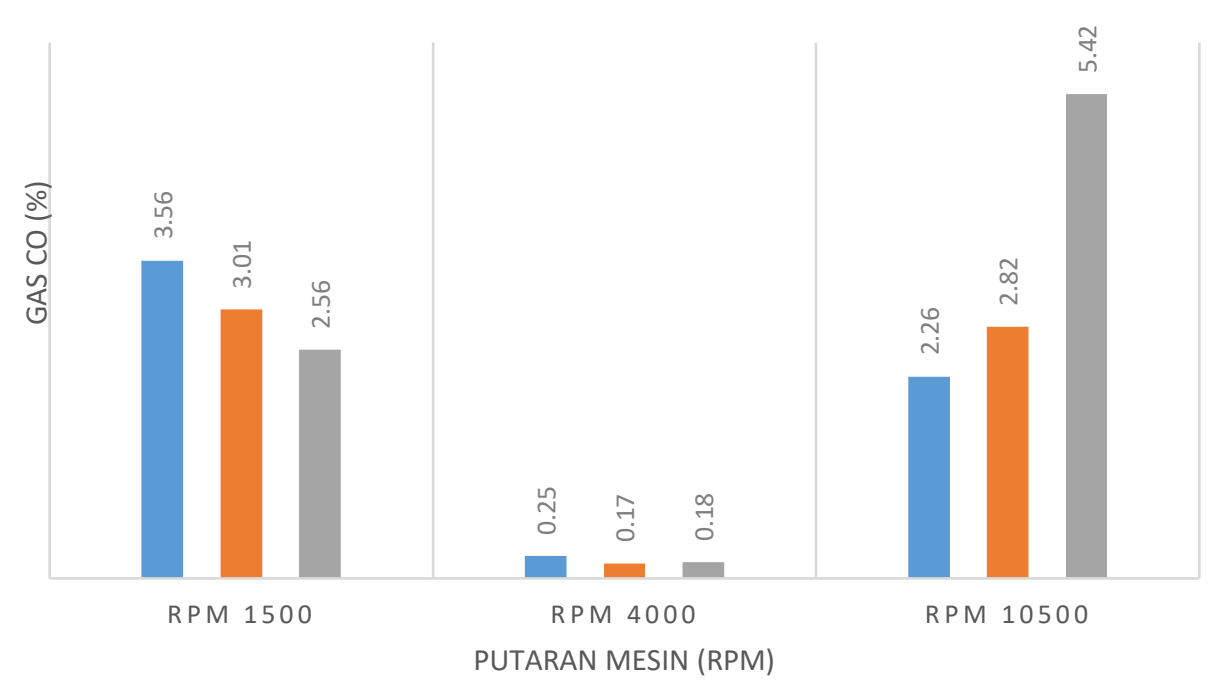

Gambar 8 Grafik hubungan rpm dengan emisi gas buang CO

Dari Gambar 4.7 memperlihatkan perbandingan kadar emisi gas buang $\mathrm{CO}$ menggunakan berbagai macam merk oli. Dimana pada rpm 1500 kadar CO tertinggi adalah yamalube dengan kadar $\mathrm{CO} 3,56 \%$ dan kadar $\mathrm{CO}$ terendah adalah enduro dengan kadar $\mathrm{CO} 2,565$. pada rpm 4000 kadar $\mathrm{CO}$ mengalami penurunan, penurunan gas Buang $\mathrm{CO}$ karena terjadi pencampuran bahan bakar dan udara yang semakin homogen atau seiambang daripada pada rpm 1500 . Apabila grsfik CO semakin turun menandakan emisi gas buang $\mathrm{CO}$ semakin sedikit dan pembakaran lebih bagus. Pada rpm 4000 kadar $\mathrm{CO}$ tertinggi adalah oli yamalube dengan kadar $\mathrm{CO} 0,25 \%$ dan kadar terendah adalah shell Ax7 dengan kadar CO 0,17\%. Pada rpm 10.500 kadar CO tertinggi adalah enduro kadar CO $5,42 \%$ dan kadar CO terendah adalah Yamalube dengan Kadar CO 2,26. Pada rpm 10500 emisi gas buang CO mengalami kenaikan emisi gas buang dibanding pada rpm 4000 dikarenakan pada rpm tinggi maka udara yang ada di dalam ruang bakar lebih sedikit daripada bahan bakar, hal tersebut yang mengakibatkan gas buang $\mathrm{CO}$ semakin banyak karena pembakaran tidak sempurna.

yamalube shell ax7 enduro

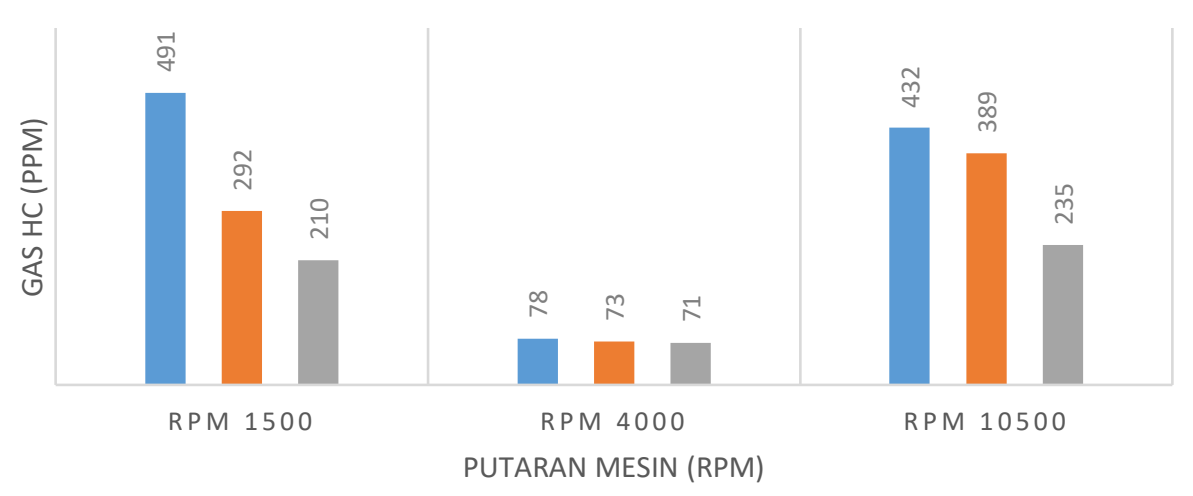

Gambar 9 Grafik hubungan rpm dengan emisi gas buang HC 
Dari Gambar 4.8 memperlihatkan perbandingan kadar emisi gas buang HC menggunakan berbagai macam merk oli. Dimana pada rpm 1500 kadar HC tertinggi adalah yamalube dengan kadar HC 491 ppm dan kadar HC terendah adalah enduro dengan kadar HC 210 ppm. pada rpm 4000 kadar HC mengalami penurunan. Gas buang HC mengalami penurunan karena pada Pada rpm 4000 pencampuran antara udara dan bahan bakarar semakin homogen atau seimbang dan pembakaran semakin sempurna yang menyebabkan gas $\mathrm{HC}$ turun. Pada rpm 4000 kadar $\mathrm{HC}$ tertinggi adalah oli yamalube dengan kadar $\mathrm{HC} 78$ ppm dan kadar terendah adalah enduro dengan kadar HC 71 ppm. Pada rpm 10500 emisi gas buang $\mathrm{HC}$ mengalami kenaikan emisi gas buang dibanding pada rpm 4000 dikarenakan pada rpm tinggi maka udara yang ada di dalam ruang bakar lebih sedikit daripada bahan bakar, hal tersebut yang mengakibatkan gas buang HC semakin banyak karena pembakaran tidak sempurna yang mengakibatkan emisi gas buang naik, gas buang naik karena ada sisa pembakaran hasil pembakaran yang kurang sempurna. Gas buang $\mathrm{HC}$ tertinggi adalah yamalube kadar $\mathrm{HC}$ 432ppm dan kadar Hc terendah adalah Enduro dengan Kadar HC 235 ppm.

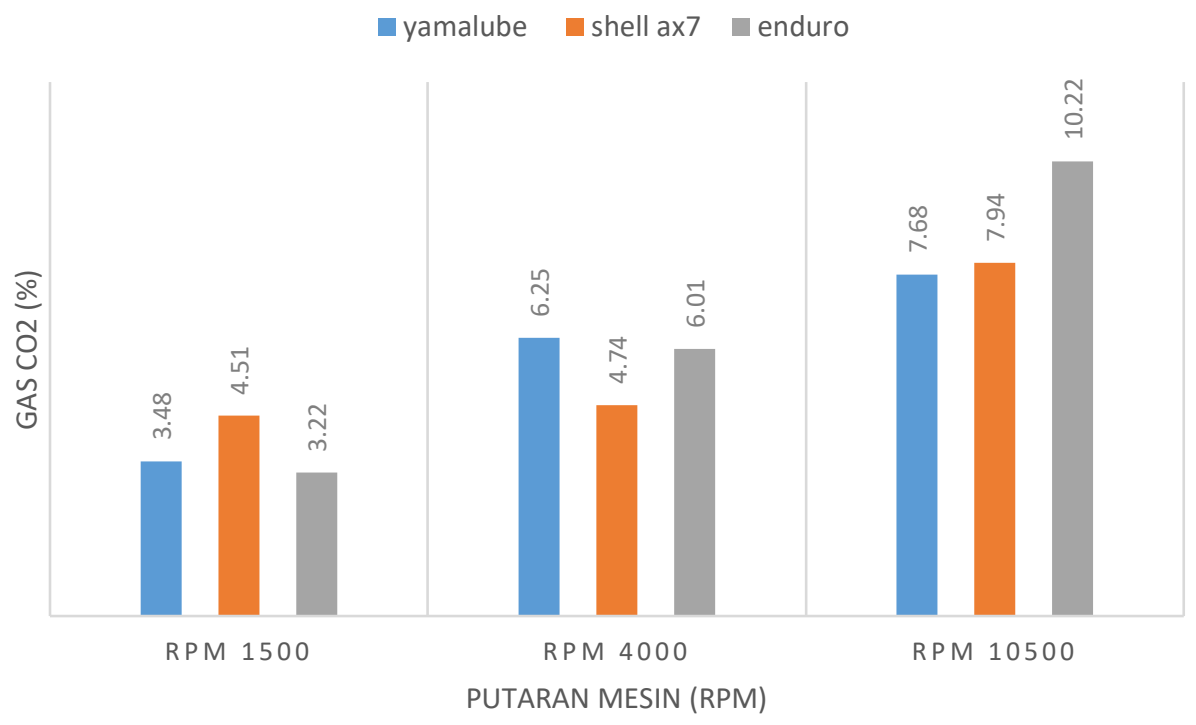

Gambar 10 Grafik hubungan rpm dengan emisi gas buang $\mathrm{CO}_{2}$

Dari Gambar 4.9 memperlihatkan perbandingan kadar emisi gas buang $\mathrm{CO}_{2}$ menggunakan berbagai macam merk oli. Dimana pada rpm 1500 kadar $\mathrm{CO}_{2}$ tertinggi adalah shell $\mathrm{Ax} 7$ dengan kadar $\mathrm{CO} 24,51 \%$ dan kadar $\mathrm{CO}_{2}$ terendah adalah enduro dengan kadar $\mathrm{CO}_{2} 3,22 \%$. Pada rpm 4000 kadar $\mathrm{CO}_{2}$ tertinggi adalah oli yamalube dengan kadar $\mathrm{CO}_{2} 6,25 \%$ dan kadar terendah adalah oli shell Ax7 dengan kadar $\mathrm{CO}_{2} 4,74 \%$. Pada rpm 10.500 kadar $\mathrm{CO}_{2}$ tertinggi adalah Enduro kadar $\mathrm{CO}_{2} 10,22 \%$ dan kadar $\mathrm{CO}_{2}$ terendah adalah yamalube dengan Kadar $\mathrm{CO}_{2} \quad 7,68 \%$. 


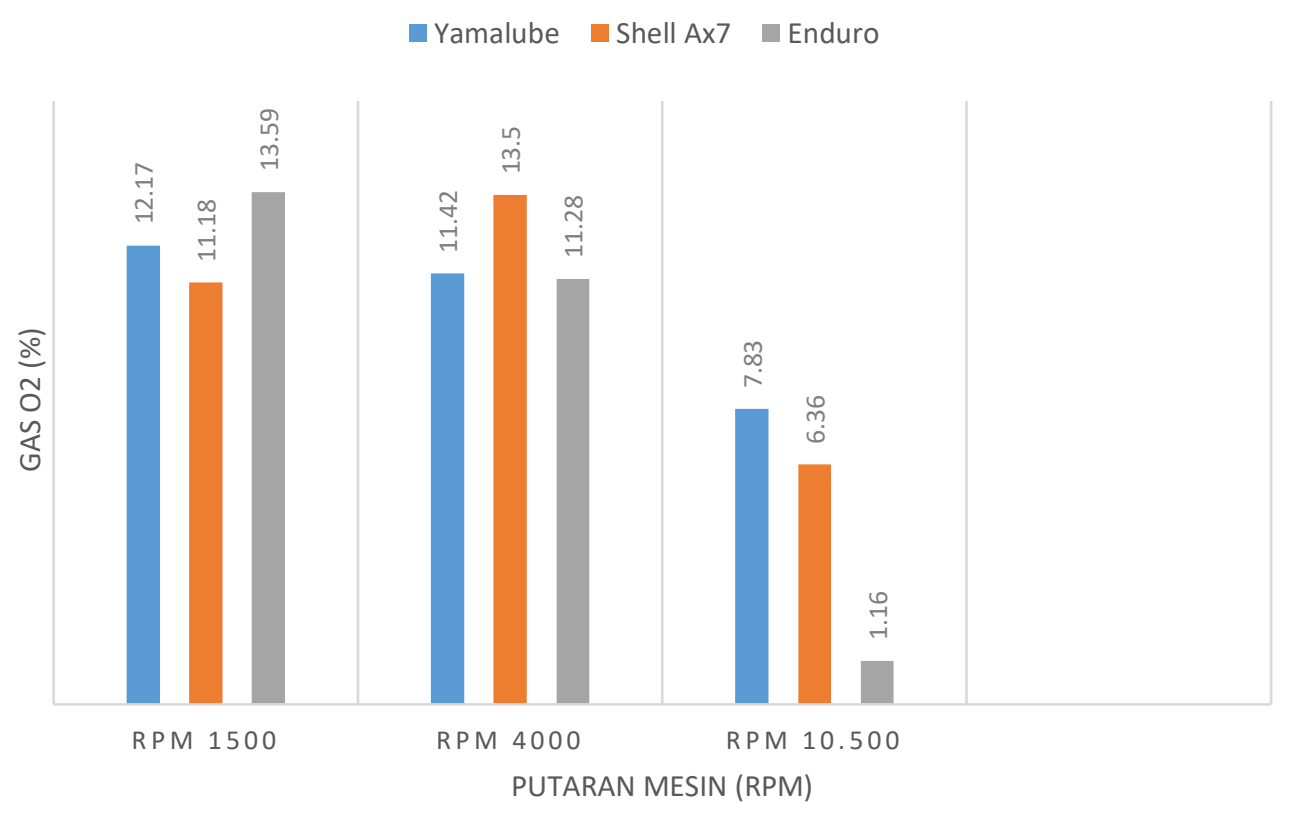

Gambar 11 Grafik hubungan rpm dengan emisi gas buang $\mathrm{O}_{2}$

Dari Gambar 11 dapat dilihat perbandingan kadar emisi gas buang $\mathrm{O}_{2}$ menggunakan berbagai macam merk oli. Dimana pada rpm 1500 kadar $\mathrm{O}_{2}$ tertinggi adalah oli enduro dengan kadar $\mathrm{O}_{2} 13,59 \%$ dan kadar $\mathrm{O}_{2}$ terendah adalah shell $\mathrm{Ax} 7$ dengan kadar $\mathrm{O}_{2} 11,18 \%$. Pada rpm 4000 kadar $\mathrm{O}_{2}$ tertinggi adalah oli shell $\mathrm{Ax} 7$ dengan kadar $\mathrm{O}_{2} 13,5 \%$ dan kadar terendah adalah oli enduro dengan kadar $\mathrm{O}_{2} 11,28 \%$. Pada rpm 10.500 kadar $\mathrm{O}_{2}$ tertinggi adalah yamalube kadar $\mathrm{O}_{2}$ $7,83 \%$ dan kadar $\mathrm{O}_{2}$ terendah adalah enduro dengan $\mathrm{Kadar} \mathrm{O}_{2} \quad 1,16 \%$.

\section{Hasil Pengujian Performa Mesin}

Dari hasil pengujian yang dilakukan untuk mengetahui pengaruh berbagai macam merk oli terhadap performa mesin vixion 150cc. Untuk pengujian terhadap performa dilakukan menggunakan dyno test pada setiap oli yang berbeda dilakukan dengan melakukan tiga kali percobaan. Data setiap oli yang diambil yaitu pada percobaan yang ke tiga. Dari hasil pengujian data yang diperoleh maka didapatkan hasil grafik sebagai berikut. 


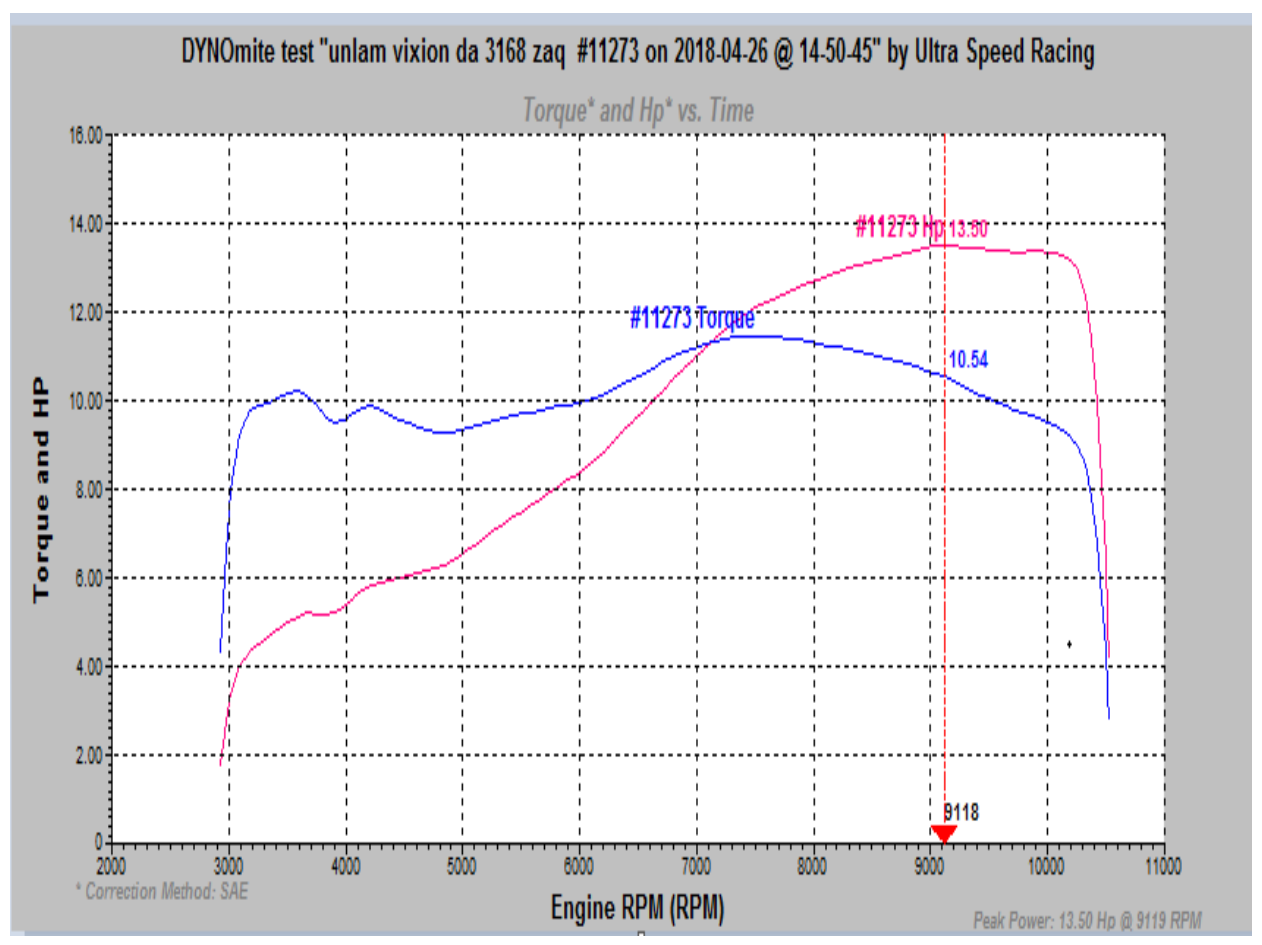

Gambar 12 Grafik performa menggunakan oli yamalube

Dari Gambar 4.11 diatas dapat kita ketahui performa yang dihasilkan mesin vixion 150 cc daya terbesar yang dihasilkan mencapai $13,49-13,50 \mathrm{HP}$ dan daya tersebut keluar di $9040 \mathrm{rpm}$. Sedangkan torsi terbesar yang di hasilkan oleh mesin vixion $150 \mathrm{cc}$ adalah $11,49 \mathrm{~N}-\mathrm{m}$ dan torsi terbesar tersebut keluar di $7509 \mathrm{rpm}$. Jadi performa terbesar yang di hasilkan oli yamalube dengan performa daya 13,50 HP dengan torsi berada pada 10,54 N-m pada putaran mesin 9118rpm.

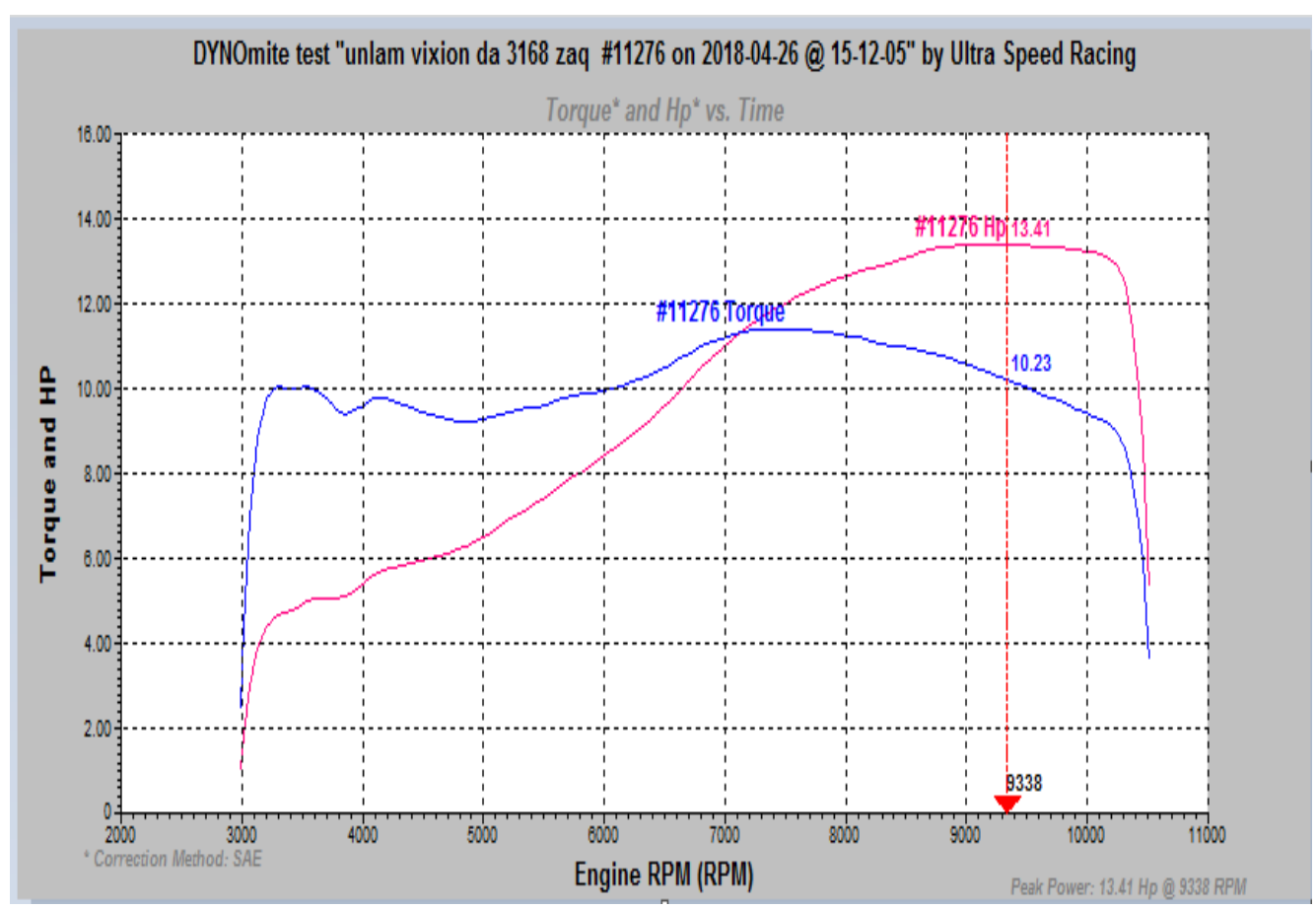

Gambar 13 Grafik Performa Menggunakan Oli shell Ax7 
Dari Gambar 4.12 diatas dapat kita ketahui performa yang dihasilkan mesin vixion $150 \mathrm{cc}$ daya terbesar yang dihasilkan mencapai $13,41 \mathrm{HP}$ dan daya tersebut keluar di 9026 rpm. Sedangkan torsi terbesar yang di hasilkan oleh mesin vixion $150 \mathrm{cc}$ adalah $11,42 \mathrm{~N}-\mathrm{m}$ dan torsi terbesar tersebut keluar di $7505 \mathrm{rpm}$. Jadi performa terbesar yang di hasilkan oli shell advance Ax7 dengan performa daya 13,41 HP dengan torsi berada pada 10,23 N-m pada putaran mesin 9338rpm.

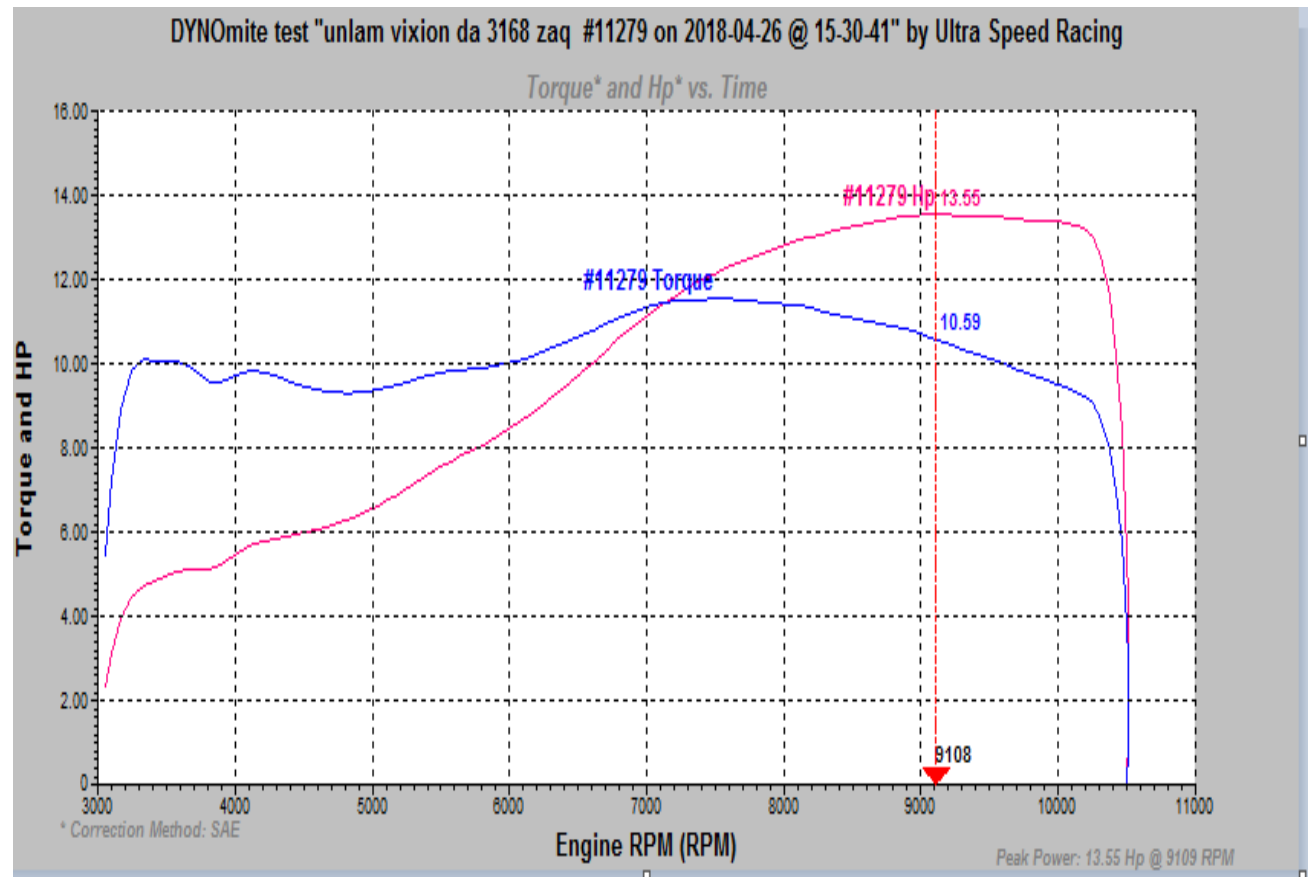

Gambar 14 Grafik performa menggunakan oli enduro

Dari Gambar 4.13 diatas dapat kita ketahui performa yang dihasilkan mesin vixion $150 \mathrm{cc}$ daya terbesar yang dihasilkan mencapai $13,55 \mathrm{HP}$ dan daya tersebut keluar di 9029 rpm. Sedangkan torsi terbesar yang di hasilkan oleh mesin vixion $150 \mathrm{cc}$ adalah $11,57 \mathrm{~N} . \mathrm{m}$ dan torsi terbesar tersebut keluar di $7311 \mathrm{rpm}$. Jadi dengan performa daya 13,55 HP dengan torsi berada pada 10,59 N-m pada putaran mesin 9029rpm.

\section{PEMBAHASAN}

Oli yamalube memiliki kode SAE 10W-40, kode tersebut di artikan sebagai kode kekentalan oli. SAE adalah singkatan dari society of automotive engineers, suatu yang mengatur standarisasi, angka 10 di sebelah kiri huruf $\mathrm{W}$ adalah nilai kekentalan oli ketika dingin. Angka 40 di sebelah huruf $\mathrm{W}$ adalah nilai kekentalan oli ketika mesin beroprasi pada suhu kerjanya sedangkan huruf $\mathrm{W}$ yang berarti (winter/musimdingin) yang berarti penggunaan sampai $-20^{\circ} \mathrm{C}$ misalnya SAE $5 \mathrm{~W}, 10 \mathrm{~W}$, atau SAE 20W. Semakin besar angka baiki kiri maupun kanan huruf W itu artinya semakin kental pada kondisinya. Oli shell advance $A \times 7$ memiliki kode SAE 10W-40 artinya oli shell advance ax7 memiliki kekentalan oli saat mesin dingin 10 dan memiliki kekentalan saat mesin beroprasi pada suhu kerjanya yaitu 40. Oli pertamina enduro memiliki kode SAE $10 \mathrm{~W}-40$ artinya yaitu memiliki kekentalan oli saat ding in 10 dan memiliki kekentalan oli saat mesin beroprasi pada suhu kerjanya 40. 
Temperatur mesin sepeda motor dengan oli yamalube lebih rendah dibandingkan dengan oli shell advance Ax7 dan enduro. Tempeatur tertinggi yang dihasilkan pada posisi $4000 \mathrm{rpm}$ dan gear posisi netral oli yamalube adalah $91,8^{\circ} \mathrm{C}$, shell advance $\mathrm{Ax} 7107,8^{\circ} \mathrm{C}$ dan enduro $113,2^{\circ} \mathrm{C}$, pada gear 1 yamalube $93,7^{\circ} \mathrm{C}$, shell advance $\mathrm{A} \times 7107,8^{\circ} \mathrm{C}$, enduro $117,8^{\circ} \mathrm{C}$, pada gear 2 yamalube $95,0^{\circ} \mathrm{C}$, shell advance $\mathrm{Ax} 7109,6^{\circ} \mathrm{C}$, enduro $114,8^{\circ} \mathrm{C}$, pada gear 3 yamalube $101,2^{\circ} \mathrm{C}$, shell advance $\mathrm{Ax} 7113,2^{\circ} \mathrm{C}$, enduro $115,2^{\circ} \mathrm{C}$, pada gear4 yamalube $105,8^{\circ} \mathrm{C}$, shell advance $\mathrm{Ax} 7115,0^{\circ} \mathrm{C}$, enduro $116,3^{\circ} \mathrm{C}$, pada gear 5 yamalube $107,3^{\circ} \mathrm{C}$, shell advance $\mathrm{Ax} 7116,7^{\circ} \mathrm{C}$, enduro $117,8^{\circ} \mathrm{C}$.

Karbon monoksida (CO) merupakan hasil dari pembakaran yang tidak sempurna yang disebabkan karena tidak seimbangnya jumlah udara pada rasio udara bahan bakar AFR. Nilai CO berdasarkan batas emisi gas buang maksimal yaitu $4,5 \%$. Berdasarkan grafik tertinggi terjadi pada oli enduro dengan putaran 10.500 rpm dengan kadar CO mencapai 5,42\%. Nilai CO yang tinggi menandakan bahwa pembakaran pada mesin sepeda motor kurang sempurna.

Hidro karbon (HC) berdasarkan batas emisi gasbuang yang di izinkan 2000 ppm. Berdasarkan grafik $\mathrm{HC}$ tertinggi terjadi pada oli yamalube dengan putaran mesin 1500 rpm dengan kadar HC 491 ppm. Nilai HC semakin tinggi menandakan karena pembakaran pada mesin sepeda motor kurang sempurna, namun gas buang yang dihasilkan tetap berada dibawah batas yang ditetapkan yaitu 2000 ppm.

Karbon Dioksida $\left(\mathrm{CO}_{2}\right)$ menunjukan secara langsung status proses pembakaran di ruang bakar semakin tinggi maka semakin baik saat AFR berada di angka ideal, emisi $\mathrm{CO}_{2}$ berkisar diantara $12 \%$ sampai $15 \%$ apabila AFR terlalu kurus atau kaya maka emisi $\mathrm{CO}_{2}$ akan turun secara drastis. Apabila $\mathrm{CO}_{2}$ berada dibawah $12 \%$, maka kita harus melihat emisi lainya yang menunjukkan AFR terllalu kaya atau terlalu kurus. Perlu di ingat bahwa sumber $\mathrm{CO}_{2}$ ini hanya ruang bakar. Apabila $\mathrm{CO}_{2}$ terlalu rendah tetapi $\mathrm{CO}$ dan $\mathrm{HC}$ normal, menunjukan adanya kebocoran pada exhaust pipe. Berdasarkan $\mathrm{CO}_{2}$ tertinggi terjadi pada oli enduro yaitu mencapai $10,22 \%$ di putaran mesin $10.500 \mathrm{rpm}$.

Oksigen $\left(\mathrm{O}_{2}\right)$ dan bahan bakar di dalam ruang bakar dapat terbakar dengan sempurna apabila bentuk dari ruang bakar tersebut melengkung secara sempurna dan campuran antara bahan bakar dan $\mathrm{O}_{2}$ yang pas. Konsentrasi $\mathrm{O}_{2}$ di gas buang kendaraan berbanding tebalik dengan konsentrasi $\mathrm{CO}_{2}$. Untuk mendapatkan proses pembakaran yang sempurna, maka kadar oksigen yang masuk keruang bakar harus mencukupi untuk setiap molekul hidro karbon. Berdasarkan data yang di dapat dapat kita liha di tabel dan grafik $\mathrm{O}_{2}$ yang tertinggi dihasilkan oleh oli enduro padaputaran mesin $1500 \mathrm{rpm}$.

Performa suatu mesin kendaraan dapat dilihat dari besarnya Torque (torsi) dan Horse power (daya/tenaga). Torsi merupakan kemampuan mesin untuk menggerakan dari kondisi diam hingga berjalan. Torsi berkaitan dengan akselarasi dalam kehidupan sehari hari sama halnya seperti ketika berkendara tubuh kita terasa terhempas kebelakan saat berkaselarasi ,hal itu menunjukan bahwa besarnya angka torsi pada mesin tersebut. Sedangkan Daya(HP) adalah kemampuan seberapa ceapt kendaraan itu mencapai suatu kecepatan tertentu. Daya (HP) paling besar yang di dapat pada pengujian ini menggunakan oli enduro yang kemudian yang kedua menggunakan oli yamalube dan yang ketiga adalah menggunakan oli shell advance Ax7. Menggunakan oli enduro Daya yang di hasilkan adalah 13,55 HP, oli yamalube menghasilkan Daya sebesar 13,50 HP, dan oli shell advance Ax7 menghasilka Daya sebesar 13,41 HP. Sedangkan torque yang tertinggi yaitu menggunakan oli endur. Oli enduro menghasilkan torque sebesar $11,57 \mathrm{~N}-\mathrm{m}$. Oli yamalube menghasilkan torque tertinggi sebesar 
$11,49 \mathrm{~N}-\mathrm{m}$, sedangkan oli shell advance Ax7 torque tertinggi yaitu 11,42 N-m. Jadi dari 3 macam oli torque yang paling besar dihasilkan yaitu oli Enduro 11,57 N-m

\section{KESIMPULAN}

Adapun kesimpulan yang di peroleh dari pungujian ini adalah sebagai berikut: Temperatur

1. Dari hasil pengujian temperatur yang telah dilakukan di dapat kesimpulan yaitu untuk menjaga temperatur mesin tidak cepat panas, oli yang paling baik yaitu menggunakan oli yamalube super sport karena oli yamalube super sport temperatur yang di hasilkan lebih rendah dari oli yang lain.

2. Dari pengujian Emisi gas buang yang telah dilakukan diperoleh kesimpulan oli yang emisi gas buangnya paling rendah yaitu oli shell advance Ax. Oli shell Ax7 menghasilkan emisi gas buang paling rendah di antara oli lainya sedangkan oli enduro melebi batas standar emisi gas buang CO di rpm 10.500 mencapai $5,42 \%$ sedangkan standarnyan yaitu $4,50 \%$ saja.

3. Dari pengujian performa yang telah dilakukan diperoleh kesimpulan performa yang paling baik yaitu menggunakan oli enduro karena oli enduro dapat menghasilkan daya paling besar yaitu $13.55 \mathrm{Hp}$, oli enduro menghasilkan daya paling besar di banding oli yang lain.

\section{DAFTAR PUSTAKA}

Antonius Piping,2013.Mengenal Sistem Pelumas.

Imam Firmansyah. Analisis Sistem Pelumasan Pada Mesin Honda Civic 16 Valve. Khairullah,2013.Sistem Pelumas Pada Kendaraan.

Mugiono Slamet, 2008. Memilih Minyak Pelumas Dan Pelumasan Dengan Benar, Malang

Muhammad Ardi, 2015. Sistem Pelumasan Pada Mesin Otomotif.Fakultas Teknik Palembang : Universitas Tridinanti Palembang.

R. Budi Mulyawan. Studi Kasus Sistem Pelumasan Dan Pengaruhnya Terhadap Sistem Komponen Mesin.

Stefan Raharjo Nugriho. Identifikasi Fisis Viskositas Oli Mesin Kendaraan Bermotor Terhadap Fungsi Suhu Dengan Menggunakna Laser Helium Neon. 